\title{
YIELD IN SAWN WOOD AND RESIDUE UTILIZATION OF Qualea paraensis DUCKE AND Erisma uncinatum WARM
}

\author{
Michelly Casagrande Stragliotto ${ }^{1 *}$, Aylson Costa Oliveira², Bárbara Luísa Corradi Pereira² ${ }^{2}$ Jefferson Melo \\ Freitas $^{3}$

\footnotetext{
${ }^{1 *}$ Federal University of Mato Grosso, Graduation Program in Forestry and Environmental Studies, Cuiabá, Mato Grosso, Brazil *michellycasagrande@gmail.com babicorradi@gmail.com
} \\ ${ }^{2}$ Federal University of Mato Grosso, Department of Forest Engineering, Cuiabá, Mato Grosso, Brazil - aylsoncosta@gmail.com; \\ ${ }^{3}$ Forestry Engineer, MADFREITAS Timber Industry, Nova Maringá, Mato Grosso, Brazil - jeffersonmelofreitas@ hotmail.com
}

Received for publication: 31/12/2017 - Accepted for publication: 06/07/2018

\begin{abstract}
The study was developed in Nova Maringá - MT. The objectives of this work were to evaluate the sawn timber yield, the use of wood residues and the quantification of products for the species Qualea paraensis (cambará) and Erisma uncinatum (cedrinho) in three diametric classes: Class A - 40.0 to $49.9 \mathrm{~cm}$; Class B - 50.0 to 59.9 $\mathrm{cm}$; Class C - 60.0 to $69.9 \mathrm{~cm}$. Four replicates per class were evaluated, totaling 12 logs per species of varied lengths. The sawn timber yield did not show a statistical difference between diametric classes for both species. Average yield for Qualea paraensis was equal to $43.97 \%$ and for Erisma uncinatum, $42.05 \%$. The residues use increased the total yield in $4.40 \%$ and $6.52 \%$ for Qualea paraensis and Erisma uncinatum, respectively. For Erisma uncinatum, the sawed products with the highest production were the board in the primary unfolding and the short board in the residues use. As for Qualea paraensis, there was more production of rafters and short battens in the same processes.

Keywords: sawmill, tropical timber, timber products
\end{abstract}

\section{Resumo}

Rendimento em madeira serrada e aproveitamento dos resíduos de Qualea paraensis ducke e Erisma uncinatum warm. Produção de madeira serrada e utilização de resíduos de Qualea paraensis Ducke e Erisma uncinatum quente. O estudo foi desenvolvido no município de Nova Maringá - MT e os objetivos foram avaliar o rendimento em madeira serrada, o aproveitamento dos resíduos madeireiros e a quantificação dos produtos serrados produzidos para as espécies Qualea paraensis (cambará) e Erisma uncinatum (cedrinho) em três classes diamétricas: Classe A - 40,0 a 49,9 cm; Classe B - 50,0 a 59,9 cm; Classe C - 60,0 a 69,9 cm, com quatro repetições por classe, totalizando 12 toras por espécie de comprimentos variados. $\mathrm{O}$ rendimento em madeira serrada não apresentou diferença estatística entre classes diamétricas para as duas espécies, sendo o rendimento médio para a Qualea paraensis igual à 43,97\% e para a Erisma uncinatum igual à $42,05 \%$. O aproveitamento dos resíduos aumentou em 4,40\% e 6,52\% o rendimento total do desdobro das toras das espécies Qualea paraensis e Erisma uncinatum, respectivamente. Para a espécie Erisma uncinatum os produtos serrados com maior produção foram a tábua no desdobro primário e a tábua curta no aproveitamento dos resíduos, enquanto que, para a espécie Qualea paraensis houve maior produção de caibro e sarrafo curto nos mesmos processos.

Palavras-chave: serraria, madeira tropical, produtos madeireiros.

\section{INTRODUCTION}

According to Marchesan et al. (2014) the timber industry is one of the main economic activities of the Amazon. The state of Mato Grosso in 2016 was the largest national producer of logs originated in native forests, registering the growth of $8.3 \%$ in comparison to the year of 2015 , which resulted in a production of 3,324,051 cubic meters of logs, i.e., $29 \%$ of the national production, according to data from the Brazilian Institute of Geography and Statistics - IBGE (IBGE, 2016). It is also worth noting that in Mato Grosso the timber industry contributes significantly to the economic development of several municipalities (IAREMA et al., 2011) through the generation of direct and indirect jobs and the development of complementary industries that attracts new investors to the cities. In the period from 2004 to 2010, the main species marketed by the state in terms of volume were: Qualea sp., Goupia glabra, Erisma uncinatum, Mezilaurus itauba, Hymenolobium sp., Apuleia sp, Manilkara sp., Cordia goeldiana, Dipteryx sp., Trattinickia sp. (RIBEIRO et al., 2016), which accounted for 88\% of the commercialized total (RIBEIRO et al., 2016).

Although the logging activity brings many benefits, there are also problems with old machinery or little

FLORESTA, Curitiba, PR, v. 49, n. 2, p. 257-266, abr/jun 2019. 
knowledge of raw material, leading to low utilization of wood, large generation of waste and increase in the cost of the final product, which are the main obstacles faced by the sector (BIASI; ROCHA, 2007; MELO et al., 2016). Thus, volumetric yield or volumetric yield coefficient is an important parameter for determining the efficiency of timber industries, being possible, then, to make decisions aiming at increasing the production of sawn wood and become a determining indicator for economic profitability industry.

The volumetric yield of sawn wood is the ratio between the volume of sawn wood produced and the volume of the log used as raw material for sawing, in percentage. According to Steele (1984), the yield of sawn wood is influenced by several factors related to wood, such as the diameter, length, conicity and quality of the logs, in addition to the variety of products, variation of dimensions during sawing, condition of equipment and method of sawing. Authors such as Murara Jr. et al. (2010) and Bonato Jr. et al. (2017) justified that mainly the quality of the $\log$ and the equipment, as well as the experience of the operator, interfere in the best utilization of the $\log$ when it is sawed.

The process of transformation of a log of circular section into pieces of rectangular and square sections is called a sawed system (MURARA Jr. et al., 2013). This procedure includes the trimming of logs to standardize the width, length and thickness, producing boards, beams, joists, rafters, plaks and others (ARO; BATALHA, 2013). In the Northern Region of Mato Grosso, according to Melo et al. (2016), the logging system is still conventional, where logs are sawed without classification and without an exact definition of a cut model, because the operator is the one who determines the way the cut will be conducted. This model results in low volumetric yield and large residue generation, increasing the production process and increasing the consumption of raw material.

Regardless of the type of timber industry, the generation of waste is a direct consequence of the primary or secondary processing of wood (PAIXÃO et al., 2014). Waste represents a problem for the environment when improperly disposed (CERQUEIRA et al., 2012). Considering that the amount of waste generated during the log sawing represents more than half of its initial volume, handling this waste and adding value to it represents an important path for a financial differential within the timber industry. Mendonza et al. (2010), reported that the best way to handle the waste is to harness them throughout the production process.

Biasi and Rocha (2007) stated that the timber industry which is not worried about improving their incomes becomes vulnerable to compete with other companies in the sector and may even paralyze their activities. In this way, the use of residues ensures the reduction of raw material costs, adds value to the products generated, contributes to environmental conservation, and makes better use of the raw material extracted from forests.

Therefore, it is necessary to know the wood yield of species in different diameter classes, as well as to take advantage of the wood residue for the production of by-products, in order to obtain a better use of raw material and consequently increase the profitability with the activity developed.

The aim of this paper is to evaluate the yield of sawn wood in the primary sawing of Qualea paraensis (cambará) and Erisma uncinatum (cedrinho) in three different diametric grades; to determine the increment in yield of wood in function of the use of residues originated from the primary sawing; and, to determine the main sawn products produced from wood of the studied species.

\section{MATERIAL AND METHODS}

The study was carried out in the MADFREITAS timber industry, located in the city of Nova Maringá, in the northern region of the state of Mato Grosso. This industry has an average processing of 500 to $1,000 \mathrm{~m}^{3} /$ month, being considered medium-sized (VITAL, 2008).

Because of its great economic importance in the Amazon Region, timber logs of the species Erisma uncinatum and Qualea paraensis were obtained from a sustainable management plan.

Twelve logs of each studied species with variable length were randomly selected into the logging yard, rated and separated into three diametric classes with four logs per class: Class A: diameters from $40 \mathrm{~cm}$ to 49.9 $\mathrm{cm}$; Class B: diameters from $50 \mathrm{~cm}$ to $59.9 \mathrm{~cm}$; Class C: diameters from 60 to $69.9 \mathrm{~cm}$.

The length and the average diameter of each log were measured with the support of a measuring tape. For the determination of average diameter, two perpendicular measurements at both edges of the logs were taken. The average diameter of each log was taken as a reference for both diametric classification and volume calculation and conicity determination.

The conicity was evaluated according to the methodology described in the Standard for Measuring and Classification of Hardwood Logs (IBDF, 1984), and calculated by the following expression: 


$$
C=\frac{\frac{d_{1}+d_{2}}{2} \frac{d_{3}+d_{4}}{2}}{L}
$$

In which: $\mathrm{C}$ for conicity $(\mathrm{cm} / \mathrm{m}), \mathrm{d} 1$ and $\mathrm{d} 2$ to perpendicular diameters of the thickest edge of the $\log (\mathrm{cm})$, $\mathrm{d} 3 \mathrm{~d} 4$ for perpendicular diameters of the finer edge of the $\log (\mathrm{cm})$ and $\mathrm{L}$ to $\log$ length $(\mathrm{m})$.

To obtain the log volume, the Smalian equation was used:

$$
V t=\frac{\pi^{*} D^{2 * L}}{40.000}
$$

In which: $\mathrm{Vt}$ for $\log$ volume $\left(\mathrm{m}^{3}\right), \mathrm{D}$ to average diameter $(\mathrm{cm})$ and $\mathrm{L}$ to log length $(\mathrm{m})$.

The used sawing system was the conventional one, where the logs are sawed according to the choice of the operator, without definition of a cut model. A simple vertical band saw with motor power of $425 \mathrm{rpm}$, flywheel diameter of $1.10 \mathrm{~m}$ and total blade length of $7.60 \mathrm{~m}$ was used to perform the main sawing.

Then, the pieces obtained in the main sawing were sent to the refill process, performed by a simple circular saw with a disc of $40 \mathrm{~cm}$ in diameter and $3.5 \mathrm{~mm}$ in thickness. A top-cutter disc with $45 \mathrm{~cm}$ diameter and $3.5 \mathrm{~mm}$ thickness was used for the topping.

The pieces obtained were separated and identified by individual log lots. The primary sawed products were quantified and classified according to CONAMA Resolution 474/2016 (BRASIL, 2016) presented in Table 1.

Tabela 1. Dimensões dos produtos serrados do desdobro primário de acordo com a Resolução CONAMA 474/2016.

Table 1. Sawn products dimensions of the primary saw according to CONAMA Resolution (474/2016).

\begin{tabular}{ccc}
\hline Product & Thickness $(\mathrm{cm})$ & Width $(\mathrm{cm})$ \\
\hline Block, Square or File * & $>12.0$ & $>12.0$ \\
Big plank & $>7.0$ & $>20.0$ \\
Plank & $4.0-7.0$ & $>20.0$ \\
Beam & $\geq 4.0$ & $11.0-20.0$ \\
Joists & $4.0-11.0$ & $8.0-10.9$ \\
Rafter & $4.0-8.0$ & $4.0-7.9$ \\
Board & $1.0-3.9$ & $>10.0$ \\
Slat & $2.0-3.9$ & $2.0-10.0$ \\
Lath & $<2.0$ & $\leq 10.0$ \\
\hline The product "Block, Square or Fillet" has a square section, so a piece of wood can only be classified in this way when its thickness and width
\end{tabular}
measures match.

To calculate the volume of lumber obtained from each sampled log, a measurement for the length $(C)$ and two measurements for the width (L) and thickness (E) at each edge of each piece was carried out with the support of a scale and a digital caliper, respectively. In this way the width and the thickness average of each piece were obtained. Then, it is possible to calculate the lumber volume determined by the following equation:

$$
\text { Vpiece }=L^{*} C^{*} E
$$

In which: Vpiece for piece volume $\left(\mathrm{m}^{3}\right), \mathrm{L}$ to average piece width $(\mathrm{m}), \mathrm{C}$ to piece length $(\mathrm{m})$ and $\mathrm{E}$ for average piece thickness $(\mathrm{m})$.

After obtaining the volume of the logs and after that the volume of lumber, the Volumetric Yield (RV) of the primary unfold of each sample was determined by the following equation:

$$
R V(\%)=\left(\left(\sum \text { Vpiece }\right) / V t\right) * 100
$$

In which: RV (\%) to volumetric yield in percentage, $\Sigma$ Vpiece for the sum of the volumes of all sawed parts of a $\log \left(\mathrm{m}^{3}\right)$ and $\mathrm{Vt}: \log$ volume $\left(\mathrm{m}^{3}\right)$.

In the industry where the present study was carried out, the waste generated during the primary sawing

FLORESTA, Curitiba, PR, v. 49, n. 2, p. 257-266, abr/jun 2019. 
through the manufacture of pieces of short sawn wood is used in the production of support for mattresses and bed rails. In view of this, the slabs and trimmings from the primary sawing were identified and separated according to the log and diametric class they belonged to, and then sent to the sector for the recovery of these residues. Thus, products called short sawn wood were obtained.

The pieces of short sawn wood obtained in the processing of residues were classified in short slats and short planks, according to Normative Instruction No. 21 of the Brazilian Institute of Environment and Natural Renewable Resources (BRASIL, 2014).

In order to estimate the volume of waste taken from each log at the end of the process, the width, thickness and length of each piece of manufactured short wood were measured, thus finding the volume of each piece and consequently the total volume of use for each log. Moreover, in order to calculate the percentage of waste utilization, the same methodology was used, i.e., the relation between the volume of pieces used by the initial log volume, according to the following equation:

$$
A P(\%)=\left(\sum V a p / V t\right) * 100
$$

In which: AP (\%) for use of residues in percentage, $\Sigma$ Vap the sum of the volume of all pieces of wood per $\log \left(\mathrm{m}^{3}\right)$ and $\mathrm{Vt}$ : $\log$ volume $\left(\mathrm{m}^{3}\right)$.

The total yield was calculated according to the equation below:

$$
R T(\%)=R V(\%)+A P(\%)
$$

In which: RT $(\%)$ for total yield in percentage, RV $(\%)$ to volumetric yield in percentage, AP (\%) for use of residues in percentage.

For the statistical analysis, a completely randomized design was used, with three treatments (diametric classes) and four repetitions (logs), totaling 12 samples per species. The results were submitted to analysis of variance (ANOVA) to verify the differences between the diametric classes evaluated. When significant differences were established between them, the Tukey test at $5 \%$ of probability was applied through the statistical program Assistat 7.7.

\section{RESULTS}

\section{Volumetric yield of primary unfold}

Table 2 shows the average values of the conicity of logs and the volumetric yield of primary logs for the three diametric grades evaluated, as well as the coefficient of variation of the volumetric yield.

Tabela 2. Conicidade das toras, rendimento volumétrico em madeira serrada (RV) e coeficiente de variação do rendimento (CV) de Qualea paraensis e Erisma uncinatum em diferentes classes diamétricas.

Table 2. Logs conicity, Sawn wood volumetric yield (RV) and yield coefficient of variation (CV) of Qualea

\begin{tabular}{|c|c|c|c|c|c|c|}
\hline \multirow[b]{2}{*}{ DIAMETRIC CLASS } & \multicolumn{3}{|c|}{ Qualea paraensis } & \multicolumn{3}{|c|}{ Erisma uncinatum } \\
\hline & $\begin{array}{l}\text { Conicity } \\
(\mathrm{cm} / \mathrm{m})\end{array}$ & RV (\%) & $\mathrm{CV}(\%)$ & $\begin{array}{l}\text { Conicity } \\
(\mathrm{cm} / \mathrm{m})\end{array}$ & $\mathrm{RV}(\%)$ & $\mathrm{CV}(\%)$ \\
\hline A & $1.30 \mathrm{a}$ & $41.49 \mathrm{a}$ & 12.10 & $1.05 \mathrm{a}$ & $38.03 \mathrm{a}$ & 37.43 \\
\hline B & $1.95 \mathrm{a}$ & $41.55 \mathrm{a}$ & 22.58 & $0.57 \mathrm{a}$ & $39.48 \mathrm{a}$ & 21.72 \\
\hline $\mathrm{C}$ & $1.46 \mathrm{a}$ & $48.86 \mathrm{a}$ & 12.62 & $2.25 \mathrm{a}$ & $48.65 \mathrm{a}$ & 18.18 \\
\hline AVERAGE & 1.57 & 43.97 & & 1.28 & 42.05 & \\
\hline
\end{tabular}
paraensis and Erisma uncinatum in different diametric classes.

The conicity did not show significant effect among the diametric classes for both evaluated species. The highest value for this parameter for species Qualea paraensis was in Class B and for Erisma uncinatum in Class C.

It can be seen in Table 2 that there was no statistical difference between the volumetric yields of Qualea paraensis in the diametric grades evaluated, being the overall average for the primary sawing of sawnwood equal to $43.97 \%$. However, the average yield of Class $\mathrm{C}$ was around $7 \%$ higher than that verified in the other diametric classes (Classes A and B).

The average yield of sawnwood from the primary sawing for the species of Erisma uncinatum was equal to $42.05 \%$, and there was no significant difference in the volumetric yield between the different diameter classes. 
Nonetheless, there is a trend of increase in yield with the increase of log diameter, with differences being verified around $9 \%$ of Class $\mathrm{C}$ in relation to Class $\mathrm{B}$.

For the two species, there is a higher yield increment for the larger diameter class (Class $\mathrm{C}$ ) in relation to the intermediate diameter class (Class B).

\section{Utilization of wood waste}

Table 3 shows the average yield values of the primary sawing residues and the total yield of sawnwood for the species Qualea paraensis and Erisma uncinatum in the three diametric grades evaluated.

Tabela 3. Valores médios de rendimento do aproveitamento de resíduos do desdobro primário (AP), coeficiente de variação $(\mathrm{CV})$ e rendimento total em madeira serrada (RT) de Qualea paraensis e Erisma uncinatum em diferentes classes diamétricas.

Table 3. Mean values of waste management yield of primary sawing (PS), coefficient of variation (CV) and sawnwood total yield (TY) of Qualea paraensis and Erisma uncinatum in different diametric classes.

\begin{tabular}{|c|c|c|c|c|c|c|}
\hline \multirow[b]{2}{*}{$\begin{array}{l}\text { DIAMETRIC } \\
\text { CLASS }\end{array}$} & \multicolumn{3}{|c|}{ Qualea paraensis } & \multicolumn{3}{|c|}{ Erisma uncinatum } \\
\hline & $\begin{array}{l}\mathrm{PS} \\
(\%)\end{array}$ & $\begin{array}{l}\mathrm{CV} \\
(\%)\end{array}$ & $\begin{array}{l}\mathrm{TY} \\
(\%)\end{array}$ & $\begin{array}{l}\text { PS } \\
(\%)\end{array}$ & $\begin{array}{l}\mathrm{CV} \\
(\%)\end{array}$ & $\begin{array}{l}\mathrm{TY} \\
(\%)\end{array}$ \\
\hline A & $3.78 \mathrm{a}$ & 24.29 & 45.28 & $7.60 \mathrm{a}$ & 44.07 & 45.63 \\
\hline $\mathrm{B}$ & $6.06 \mathrm{a}$ & 51.20 & 47.62 & $6.02 \mathrm{a}$ & 20.01 & 45.51 \\
\hline $\mathrm{C}$ & $3.37 \mathrm{a}$ & 9.77 & 52.24 & $5.94 \mathrm{a}$ & 12.83 & 54.59 \\
\hline AVERAGE & 4.40 & & 48.38 & 6.52 & & 48.58 \\
\hline
\end{tabular}

Averages followed by the same letter in the column do not differ statistically from each other, by the Tukey test at $5 \%$ significance.

As observed in Table 3, although there was no statistical difference between the diametric classes, for species Qualea paraensis, Class B obtained greater use of residues (6.06\%) and for species Erisma uncinatum Class A (7.60\%) was the one that presented the highest average result of use of wood residues.

The greatest variation in total yield values between the diametric classes for the species of Erisma uncinatum was the increase of $9 \%$ for Class B to C. For Qualea paraensis, the highest variation also occurred in these same diametric grades, however with a less expressive difference, $4.62 \%$.

\section{Wood products}

Table 4 shows the quantities of sawed products from the primary sawing of the species Qualea paraensis and Erisma uncinatum in the different diametric grades.

Tabela 4. Produtos do desdobro primário por classe diamétrica das espécies Qualea paraensis e Erisma uncinatum e seus respectivos volumes.

Table 4. Primary sawing products by diametric class of Qualea paraensis and Erisma uncinatum and their respective volumes.

\begin{tabular}{|c|c|c|c|c|c|c|c|c|}
\hline \multirow{2}{*}{ Products } & \multicolumn{3}{|c|}{ Qualea paraensis } & \multicolumn{5}{|c|}{ Erisma uncinatum } \\
\hline & $\mathrm{A}$ & $\mathrm{B}$ & $\mathrm{C}$ & $\operatorname{Vol}\left(\mathrm{m}^{3}\right)$ & $\mathrm{A}$ & $\mathrm{B}$ & $\mathrm{C}$ & $\operatorname{Vol}\left(\mathrm{m}^{3}\right)$ \\
\hline Lath & 8 & 12 & 18 & 0.09 & 7 & 7 & 33 & 0.16 \\
\hline Slat & 29 & 24 & 20 & 0.33 & 48 & 79 & 53 & 0.83 \\
\hline Board & 4 & 5 & 15 & 0.66 & 68 & 89 & 130 & 7.12 \\
\hline Beam & 24 & 49 & 25 & 3.17 & - & - & - & - \\
\hline Joists & 5 & 18 & 14 & 1.15 & - & - & - & - \\
\hline Rafter & 36 & 14 & 87 & 1.78 & - & - & - & - \\
\hline TOTAL & 106 & 122 & 179 & 7.19 & 123 & 175 & 216 & 8.10 \\
\hline
\end{tabular}

A $\varnothing$ from $40 \mathrm{~cm}$ to $49.9 \mathrm{~cm}$; B: $\varnothing$ from $50 \mathrm{~cm}$ to $59.9 \mathrm{~cm}$; C: $\varnothing$ from $60 \mathrm{~cm}$ to $69.9 \mathrm{~cm}$; Vol: Volume $\left(\mathrm{m}^{3}\right)$

In the primary sawing of Qualea paraensis, laths, slats, boards, beams, joists, and rafters were made, being the rafter the one most produced, representing 33.66\% of the total production of the species and the board was the one that presented the lowest production, corresponding to $5.89 \%$ of the total produced. For lath and board, there was an increase in the number of products according to the increase of the diameter class. The oscillations between the diametric grades were observed for the beam, joist and rafter. The slat was the only one in which the production decreased as the diameter classes increased.

For the Erisma uncinatum, only laths, slats and boards were produced. Boards presented the highest production, corresponding to $55.83 \%$ of the total produced by the species and the lath was the one that obtained the lowest production, being $9.14 \%$. With the exception slats in Class $\mathrm{C}$ and lath in Class $\mathrm{B}$, this species tended to increase the number of products as the diameter class increased. 
However, for both species, the total number of pieces produced (Table 4) increased as the diameter class increased.

Table 5 shows the quantities of short wood products originated from the use of residues by diameter class of species Qualea paraensis and Erisma uncinatum.

Tabela 5. Produtos de madeira serrada curta advindos do aproveitamento dos resíduos de Qualea paraensis e Erisma uncinatum em diferentes classes diamétricas e seus respectivos volumes.

Table 5. Short sawn products of the waste management of Qualea paraensis and Erisma uncinatum in different diametric classes and their respective volumes.

\begin{tabular}{|c|c|c|c|c|c|c|c|c|}
\hline \multirow{2}{*}{ Products } & \multicolumn{3}{|c|}{ Qualea paraensis } & \multicolumn{5}{|c|}{ Erisma uncinatum } \\
\hline & $\mathbf{A}$ & B & C & $\operatorname{Vol}\left(\mathrm{m}^{3}\right)$ & $\mathbf{A}$ & B & C & $\operatorname{Vol}\left(\mathrm{m}^{3}\right)$ \\
\hline $\begin{array}{c}\text { Short slats } \\
(0.023 \mathrm{mx} 0.043 \mathrm{mx} 0.68 \mathrm{~m})\end{array}$ & 209 & 435 & 355 & 0.67 & 192 & 219 & 285 & 0.47 \\
\hline $\begin{array}{c}\text { Short board (I) } \\
(0.023 \mathrm{~m} \times 0.10 \mathrm{~m} \times 0.24 \mathrm{~m})\end{array}$ & - & - & - & & 263 & 305 & 585 & 0.64 \\
\hline $\begin{array}{c}\text { Short board (I) } \\
(0.023 \mathrm{~m} \times 0.10 \mathrm{~m} \times 0.17 \mathrm{~m})\end{array}$ & - & - & - & & 28 & 34 & 40 & 0.04 \\
\hline TOTAL & 209 & 435 & 355 & 0.67 & 483 & 558 & 910 & 1.14 \\
\hline
\end{tabular}

A $\varnothing$ from $40 \mathrm{~cm}$ to $49.9 \mathrm{~cm}$; B: $\varnothing$ from $50 \mathrm{~cm}$ to $59.9 \mathrm{~cm}$; C: $\varnothing$ from $60 \mathrm{~cm}$ to $69.9 \mathrm{~cm}$; Vol: Volume $\left(\mathrm{m}^{3}\right)$

In the use of wood residues, two types of short sawn timber were manufactured: the short slat with dimensions of $0.023 \mathrm{mx} 0.043 \mathrm{mx} 0.68 \mathrm{~m}$, which are commercialized for the preparation of bed rails, and two types of products called short boards, with dimensions of $0,023 \mathrm{mx} 0,1 \mathrm{~m} \times 0,17 \mathrm{~m}$ and $0,023 \mathrm{mx} 0,1 \mathrm{~m} \times 0,24 \mathrm{~m}$, used for the construction of the structural part of mattresses.

According to Table 5, for species Qualea paraensis the production was only concentrated on the manufacture of short slats. There was no tendency to increase the production of pieces as the diameter class of the logs increased. Nonetheless, Class B, which presented the highest yield in the recovery of residues (Table 3), was the class that presented the highest quantity of pieces produced.

For the species Erisma uncinatum there is a trend of increasing the number of pieces as the diametric grades increase. For this species, the short board I was the product with the highest production in all classes, followed by the short slat.

When analyzing the percentage of waste utilization (Table 3) and the total number of pieces produced (Table 5), it can be observed that Erisma uncinatum obtained greater use of the residues and greater quantity of pieces produced, with values equal to $6.52 \%$ and 1,951 pieces, respectively. While Qualea paraensis presented values equal to $4.41 \%$ and 999 for use of the residues and produced pieces, respectively. However, the amount of short slats of Qualea paraensis was greater than the amount produced by Erisma uncinatum.

\section{DISCUSSION}

\section{Volumetric yield of primary sawing}

The values of conicity found in this work are in agreement with those found by Garcia et al. (2012) studying the tropical species Couratari guianensis and Mezilaurus itauba, in which the conicity values of evaluated logs ranged from $0.35 \mathrm{~cm} / \mathrm{m}$ to $3.65 \mathrm{~cm} / \mathrm{m}$. According to the Standard for Measurement and Classification of Hardwood Timber Logs (IBDF, 1984), the logs of the present work can be considered of excellent quality for the production of sawn timber, since they have a conicity value of less than $3 \mathrm{~cm} / \mathrm{m}$, being framed in the Upper Class, the first class according to such Standard.

According to data from Table 2, the volumetric yield found in this work for species Qualea paraensis was lower than the value found by Melo et al. (2016) when evaluating Qualea sp. in a sawmill in the city of Sorriso-MT, where they found an average yield of $52.18 \%$ for diameters up to $75 \mathrm{~cm}$. Biasi and Rocha (2007) carried out the study of the yield of sawn wood in the city of Sinop-MT, in logs of the species Qualea albiflora with diameters varying from 31 to $70 \mathrm{~cm}$, they found average yield value equal to $62.63 \%$, not verifying significant effect among diametric classes, as in this work. Probably, the highest yield found by Biasi and Rocha (2007) is due to the higher quality of the evaluated logs, which, according to the authors, presented small clenches and cracks, without compromising the yield of sawn wood. In the present study, Qualea paraensis logs presented tortuosity and cracking that resulted in the lowest yield found.

The presence of tortuous logs in Class B of species Qualea paraensis probably resulted in a higher coefficient of variation and small increase in yield of this class whose difference for class A was very small. Therefore, the quality of the log affects the production of sawn wood and decreases the yield and thus, by deploying 
good quality logs, it is possible to reduce the amount of waste and increase the yield in the process (GARCIA et al., 2012; JUIZO et al., 2015).

The increase in the yield of lumber around 7\% in Class $\mathrm{C}$ compared to the other classes of the species Qualea paraensis, when considered in an industrial process of production is significant, reducing the generation of residues and possibly raising the revenue for the company, due to the increased production of sawn wood.

Biasi and Rocha (2007) studied the species Erisma uncinatum in four diametric classes, with diameters varying between 31 and $70 \mathrm{~cm}$, in a timber industry in Mato Grosso, finding the average volume yield equal to $59.83 \%$. These same authors also verified that there was no significant difference between the yields of the diametric grades evaluated, as well as in the present work.

According to data in Table 2, the increase in yield according to the increment of the log diameter can be explained by Wade et al. (1992), due to the volume of wood lost with slabs and shavings represent a smaller percentage in relation to the log volume.

It should be noted that the low volumetric yields of Classes A and B are due to the fact that some Erisma uncinatum logs show tortuosity, being observed in these classes coefficients of variation above $20 \%$, reaching almost $40 \%$ for Class A (Table 2). Piovesan et al. (2013) studying the yield of sawnwood for a tropical species reported that the large variation between the highest and lowest yields is mainly due to the quality of the logs, since the process, the equipment and the work team were the same for all logs evaluated, as well as in the present work.

It was also observed that a class A log, whose yield was equal to $19.87 \%$, besides presenting the tortuous shaft, it was attacked by xylophages, evidencing the influence of the quality of the logs on the volumetric yield of the sawn wood. According to Juizo et al. (2015), the presence of hollows and attack by xylophagous organisms significantly affect the yield, as a consequence of the reduction of the volume of wood to be deployed.

Araújo et al. (2014) examining the sawnwood yield for the tropical species Parkia multijuga (faveira) found the average yield of $44.12 \%$, which is close to the one found in this study for both species (Table 2). Nonetheless, when comparing the average yield values of the species evaluated in the present study, a small difference between the results obtained was observed (Table 2). For Erisma uncinatum, it was obtained a lower average yield, resulting in lower productivity and greater generation of residues, when compared to Qualea paraensis.

The average volumetric yield of sawnwood for the species Qualea paraensis and Erisma uncinatum in the primary sawing was higher than the value of $35 \%$ of wood yield determined by resolution CONAMA 474/2016 (BRASIL, 2016). In this way, it is emphasized that the industry where the study was performed shows higher productivity than the legislation provides.

\section{Utilization of wood residues}

The average amount of residues generated in the primary sawing was approximately $57 \%$, and the main residues formed were slabs, wanes, sawdust and wood shavings. The value of the amount of residues generated in the present study is close to 56\%, found by Araújo et al. (201.4), and to 55\%, found by Melo et al. (2012), both also studying native species of the Amazon region.

The highest percentage of waste utilization was for Erisma uncinatum (Table 3). This result can be explained by the lower values of medium primary yield for Classes A and B, lower than $40 \%$ (Table 2), resulting in a higher volume of residues to be sent to the recovery stage. The use of residues of species Qualea paraensis was lower, due to the higher yield found in the primary sawing.

For Erisma uncinatum, it was verified that according to the increase of the diameter of the log the percentage of use of residues decreased, being justified by the greater yield in the primary sawing of the larger diametric classes. This same trend was not observed for Qualea paraensis (Table 3).

According to Table 3, the total yields for the two species were similar, approximately $48 \%$. For the species Qualea paraensis, there was little increasement in the total yield after the use of residues, due to the higher primary yield. As for the Erisma uncinatum, the greater use of residues provided an increase in the total yield.

It is worth mentioning that the use of wood residues increases the use of raw material from the forest, becoming important from an economic and environmental point of view, since when wood is better used, the quantity of wood exploited in forests for the production of the same volume of products is reduced.

\section{Wood products}

According to Garcia et al. (2012), sawmills produce a great diversity of products such as planks, big planks, blocks, boards, rafters, beams, joists, slats, props, laths and others. Table 4 shows a greater diversity of products for Qualea paraensis, whereas for Erisma uncinatum only laths, slats, and boards were produced. This difference in the diversity of products results in different yields in the primary sawing (Table 2), since the greater

FLORESTA, Curitiba, PR, v. 49, n. 2, p. 257-266, abr/jun 2019. 
diversity of production allows better use of raw material, admitting a production of pieces with varied dimensions, which assists in the reduction of waste generation.

For the species Erisma uncinatum, there was greater use of residues, due to the greater production of short wood pieces with different lengths $(17,24$ and $68 \mathrm{~cm})$. As for the Qualea paraensis, in which the production was only of short slats $(68 \mathrm{~cm})$, the percentage of residue use and the production of short wood pieces was smaller, since the wood is better utilized when the dimensions of the parts are smaller and/or when there is a production of parts with varying dimensions.

The higher production of short wood pieces for Class $\mathrm{C}$ of the species Erisma uncinatum can be attributed to the greater conicity found for this class. Because of this fact, the yield in the primary sawing may have been compromised, resulting in a higher volume of wood for the manufacture of short sawn timber.

Due to the difference in value of the cubic meter of lumber between the species and types of products, the revenue generated by the commercialization of these species will be different. The lumber from the primary forest has a higher market value, when compared to the wood obtained from the use of wood residues, due to the dimensions of the pieces.

In order to demonstrate how the use of wood residues can contribute to increase the revenues of an industry, despite the sampling being small and the presence of high coefficients of variation, a case study was carried out, considering values referring to March 2018 and the results obtained in this study.

The value of the cubic meter in log in the sawmill's yard for the species Qualea paraensis is $\mathrm{R} \$ 150.00$. After the sawing, the value of lumber starts to be commercialized according to the products generated. For this species, the commercial value of cubic meter of boards, beams, joists and rafters are R\$1200.00 + ICMS + Freight, on the other side, laths and slats are traded at R $\$ 1100.00+$ ICMS + Freight. According to the volumes of each type of product produced (Table 4), it is possible to find an average value for the price of lumber in the primary yard about $R \$ 1194.15$. The short woods from the process of waste restoration are traded at $R \$ 200.00$ per cubic meter.

Thus, to acquire 1000 cubic meters of $\log$ of Qualea paraensis, it would be spent $\mathrm{R} \$ 150,000.00$ and after the sawing, it would be generated an average revenue of $R \$ 525,068.20$ of lumber in the primary sawing and $R \$$ $8,800.00$ with utilization of residues, considering the yields found for these stages (Tables 2 and 3 ). The revenue generated would be 3.5 times higher than the cost of logging, disregarding the other costs involved in the process.

For the species Erisma uncinatum, the commercial value of the cubic meter of log placed in the yard of the sawmill is R $\$ 230.00$ and the lumber is R $\$ 1250.00$ + ICMS + Freight for board and R\$1100,00 + ICMS + Freight for lath and slat. With the data of the sawed products volume presented in Table 4, the average value of the cubic meter of sawed wood verified for the species is $R \$ 1231.82$. The value of the cubic meter of the short woods is also commercialized at $R \$ 200.00$.

Therefore, to acquire 1000 cubic meters of log of Erisma uncinatum, it would be spent $\mathrm{R} \$ 230,000.00$, generating an average revenue for the commercialization of products of the primary sawing equal to $\mathrm{R} \$ 517,982.90$ and for the short woods provinient of the use of residues, this revenue would be $\mathrm{R} \$ 13,040.00$, resulting in a revenue 2.2 times higher than the cost of logs.

In this way, considering only the acquisition values of logs and the sale of sawn timber from primary sawing and shortwood, the species Qualea paraensis may present greater gain. Considering the gross value of the cubic meter of wood commercialized in Mato Grosso, without considering other costs in the production process, it is possible to verify an average increase of about $2 \%$ in the industry revenue, due to the use of residues generated in the primary sawing.

\section{CONCLUSION}

- The primary yield for both species was satisfactory and there was an increase trendin the yield as the log diameter increased.

- The use of wood residues for the manufacture of sawn wood of the two species is shown as an alternative way to improve the yield of the raw material.

- The main sawed products obtained during the primary sawing for the species Qualea paraensis and Erisma uncinatum were respectively rafter and board. On the other hand, the main products manufactured in the stage of waste restoration were short slat for Qualea paraensis and short board with dimension of $0.023 \mathrm{~m} \times 0.10 \mathrm{~m}$ x $0.24 \mathrm{~m}$ for the Erisma uncinatum. 


\section{ACKNOWLEDGMENTS}

To CAPES, for granting the Master's degree to the principal author, to the Federal University of Mato Grosso and to MADFREITAS timber industry for enabling the development of this research.

\section{REFERENCES}

ARAÚJO, J de. A.; COSTA, N. S DA.; LIMA, R DA. S.; CALDERON, C. M. A.; CALDERON, R de, A. Rendimento e eficiência operacional do desdobro da madeira de faveira (Parkia multijuga Benth. - Fabaceae). Enciclopédia Biosfera, Centro Científico Conhecer, Goiânia, v.10, n.19, p. 1657-167, 2014.

ARO, E. R.; BATALHA, M. O. Competitividade da madeira serrada do estado de Mato Grosso - Brasil. Gestão \& Regionalidade, v. 29, n. 87, p. 81-94, set-dez. 2013.

BIASI, C. P.; ROCHA, M. P. Rendimento em madeira serrada e quantificação de resíduos para três espécies tropicais. Revista Floresta, Curitiba, v. 37, n. 1, jan/abr, p. 95-108, 2007.

BONATO JR., A. I.; ROCHA, M. P. da; JUIZO, C. G. F.; K., R. J.; Efeito do sistema de desdobro e das classes diamétricas no rendimento em madeira serrada de Araucaria angustifolia. Revista Floresta e Ambiente, v. 24, 2017.

BRASIL. Instrução No 9, de 12 de dezembro de 2016. Diário Oficial Da União, Brasília, DF, treze de dezembro de 2016. Disponível em: < https://www.jusbrasil.com.br/diarios/133206813/dou-secao-1-13-12-2016-pg63/pdfView>. Acesso 04 nov. 2017.

BRASIL. Resolução no 474, de 6 de abril de 2016. Altera a Resolução no 411, de 6 de maio de 2009. Dispõe sobre procedimentos para inspeção de indústrias consumidoras ou transformadoras de produtos e subprodutos florestais madeireiros de origem nativa, bem como os respectivos padrões de nomenclatura e coeficientes de rendimento volumétricos, inclusive carvão vegetal e resíduos de serraria, e dá outras providências. Diário Oficial da União, Brasília, DF, seis de abril de $2016 . \quad$ Disponível em: < http://www.mma.gov.br/port/conama/legiabre.cfm?codlegi=720>. Acesso 07 nov. 2017.

CERQueIRA, P. H. A.; VIEIRA. G. C.; BARBERENA. I. M.; MELO, L. C.; FREITAS, L. C. Análise dos Resíduos Madeireiros Gerados Pelas Serrarias do Município de Eunápolis-BA. Revista Floresta e Ambiente, Seropédica, v.19, n.4, p. 506 - 510, 2012.

GARCIA, F. M; MANFIO, D. R.; SANSÍGOLO, C.A.; MAGALHÃES, P. A.D. Rendimento no desdobro de toras de Itaúba (Mezilaurus itauba) e Tauari (Couratari guianensis) segundo a classificação da qualidade da tora. Revista Floresta e Ambiente, v.19, n. 4, out/dez, p. 468-474. 2012.

IAREMA, A. A.; FONTE, L. E. F.; FERNANDES, R. B. A.; SCHAEFER, C. E. G. R.; PEREIRA, L. C. Qualidade física e química do solo em áreas de exploração florestal no Mato Grosso. Revista Árvore, Viçosa, v.35, n.3, Edição Especial, p. 737-744, 2011.

INSTITUTO BRASILEIRO DE DESENVOLVIMENTO FLORESTAL-IBDF. Norma para edição e classificação de toras de madeiras de folhosas. Brasília: IBDF; 1984.

INSTITUTO BRASILEIRO DE GEOGRAFIA E ESTATÍSTICA - IBGE. Produção da Extração Vegetal e da Silvicultura 2016. Rio de Janeiro, v. 31, p.1-54, 2016.

JUIZO, C. G. F.; LOIOLA, P. L. ; MARCHESAN, R. ; VASCONCELOS, C. G. ; CHAORA, I. J. ; ROCHA, M. P. ; KLITZKE, R. J. . Influência da classe diamétrica no rendimento em madeira serrada de duas espécies nativas de Moçambique. Pesquisa Florestal Brasileira, v. 35, p. 293-298, 2015.

MELO, L. E. L.; SILVA, C. J.; LOPES, K. V.; BRITO, P. G. M; SANTOS, I. S.. Resíduos de serraria no estado do Pará: caracterização, quantificação e utilização adequada. Revista Floresta e Ambiente, v. 19, p. 133-116, 2012.

MELO, R. R.; ROCHA, M. J.; RODOLFO JR, F.; STANGERLIN, D. M. Análise da influência do diâmetro no rendimento em madeira serrada de cambará. Pesquisa Florestal Brasileira, Colombo, v. 36, n. 88, out/dez., p. 393-398, 2016.

MENDONZA, Z. M. S. H.; EVANGELISTA, W. V.; ARAÚJO, S. O.; SOUZA, C. C.; RIBEIRO, F. D. L.; SILVA de, J. C. Análise dos resíduos madeireiros gerados nas marcenarias do município de Viçosa - Minas Gerais. Revista Árvore, Viçosa, v. 34 n. 4, jul/ago, p. 755-760, 2010.

FLORESTA, Curitiba, PR, v. 49, n. 2, p. 257-266, abr/jun 2019. 
MARCHESAN, R.; ROCHA, M. P.; SILVA, J. B.; KLITZKE, R. J. Eficiência técnica no desdobro principal de toras de três espécies tropicais. Floresta, Curitiba, v. 44, n. 4, p. 629 - 636, out-dez, p.629-636, 2014.

MURARA JR., M. I.; ROCHA M. P.; TRUGILHO, P. F. Estimativa do rendimento em madeira serrada de pinus para duas metodologias de desdobro. Revista Floresta e Ambiente, v. 20, n. 4, p. 556-563, 2013.

MURARA JR., M. I.; ROCHA M. P.; TIMOFEICZYK JR, R. Análise dos custos do rendimento em madeira serrada de Pinus taeda para duas metodologias de desdobro. Floresta, Curitiba, v. 40, n. 3, p. 477-484, jul/set. 2010.

PAIXÃO, C. P. S.; FERREIRA, E.; STACHIW, R. Produção e destinação dos resíduos gerados em serrarias no município de Rolim de Moura - RO. Revista Brasileira de Ciências da Amazônia, Rolim de Moura, v. 3, n. 1, p. 47-56, 2014.

PIOVESAN, P. R. R.; REIS, A. R. S.; SOUZA, D. V. Rendimento na produção de madeira serrada de ipê (Handroanthus sp). Enciclopédia Biosfera, Goiânia, v. 9, n. 17, p. 2315-2329, 2013.

RIBEIRO, E. S.; SOUZA, R. A. T. M.; PAULA, M. H.; MESQUITA, R. R. S.; MOREIRA, E. L.; FAZION. H. Espécies florestais comercializadas pelo estado de Mato Grosso. Biodiversidade, Rondonópolis, v. 15, n. 2, p. 2$20,2016$.

STEELE, P.H. Factors determining lumber recovery in sawmilling. Gen. Tech. Rep. FPL-39. Madison, WI:.S. Department of Agriculture. Forest Service. Forest Products Laboratory, 1984. 8 p.

WADE, M. W.; BULLARD, S. H.; STEELE, P. H.; ARAMAN, P. A. Estimating hardwood sawmill conversion efficiency based on sawing machine and log characteristics. Forest Products Journal, Madison, v. 42, n. 11/12, p. 21-26, 1992. 